\title{
Governing economic interests: Interwar road construction in Belgian Congo
}

La gouvernance des intérêts économiques: La construction de routes coloniales pendant l'entre-deux-guerres au Congo belge

\section{Laurence Heindryckx}

\section{(2) OpenEdition}

\section{Journals}

Electronic version

URL: http://journals.openedition.org/belgeo/43202

DOI: $10.4000 /$ belgeo.43202

ISSN: 2294-9135

Publisher:

National Committee of Geography of Belgium, Société Royale Belge de Géographie

Electronic reference

Laurence Heindryckx, "Governing economic interests: Interwar road construction in Belgian Congo", Belgeo [Online], 1 | 2020, Online since 28 October 2020, connection on 20 January 2021. URL: http:// journals.openedition.org/belgeo/43202 ; DOl: https://doi.org/10.4000/belgeo.43202

This text was automatically generated on 20 January 2021.

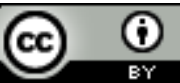

Belgeo est mis à disposition selon les termes de la licence Creative Commons Attribution 4.0 International. 


\title{
Governing economic interests: Interwar road construction in Belgian Congo
}

\author{
La gouvernance des intérêts économiques : La construction de routes coloniales \\ pendant l'entre-deux-guerres au Congo belge
}

Laurence Heindryckx

The author wants to acknowledge the insightful comments of Professor Johan Lagae during the writing of this paper. Additionally, the author wishes to thank Professor Jacob Sabakinu Kivilu and Dr. Gillian Mathys for their observations on previous versions of this paper, as well as Dr. David Peleman for his remarks on the research conducted for the Master's dissertation which was at the base of the paper. Further thanks go to Dr. Ana Vaz Milheiro and Dr. Barbara Lipietz (II International Conference African Urban Planning, Lisbon, 2017).

\section{Introduction}

1 Compared to the railroad and fluvial networks, road infrastructure remains a blank spot in the historiography of colonial planning in Congo, and by extension, in the entire continent. Nonetheless, the colonial road network was used to efficiently carry out the health care program, tax system, postal service, and the military control system, which Freed called the 'networks of colonial power' (Freed, 2010). From a diffusionist standpoint that polarises 'Western' and 'indigenous' technologies, one could hypothesise that road infrastructure thus equally served as a tool of empire during the Belgian colonisation (Headrick, 1981). However, the analysis of the interwar road construction in the Bas-Congo region leads us to question this concept of tool of empire, striving for 'a more interactive, culturally-nuanced, multi-sited debate about how technology functions within specific parameters of time, place and culture' (Arnold, 2005). 
2 As road construction implies access to land, recruitment of labour, and a means of extraction of goods, the road network in the colonial context is inevitably linked to ideas of power, culture and identity. Road construction in Belgian Congo was thus closely related to the development of missionary congregations (Cleys et al., 2019; Cleys, De Meulder, 2011), investment strategies of private capital, politics of the colonial government administration, and various levels of African agency. In line with David Peleman's Les Hommes de la Route for Belgium (Peleman, 2013), the overall goal of this research is to unveil who were some of the main actors involved in the design and production of the colonial road network, and what were their agendas. Focussing on the evolution of the road network built in Belgian Congo during the interwar period, this article studies two of these specific actors: the colonial government and private entrepreneurs. In particular, the analysis of the case of interwar road construction in the Cataractes-Nord region illustrates how private entrepreneurs deployed the colonial government's road policies in their favour by carefully responding to governance sensitivities in order to access the colonial hinterland. Contrary to the still dominant discourse on the history of colonial planning (Scott, 1998; Young, 1994), the case illustrates as such how everyday colonial policymaking in Belgian Congo was deeply reliant on the capabilities and motives of government officials and private entrepreneurs 'on the ground'.

3 Existing studies on transportation in Congo, including those dating from the 1950s and 60 s, have been limited almost exclusively to fluvial navigation, the development of airlines and, most importantly, the railway network (Blanchart, 1993; Katzellenbogen, 1973; Lederer, 1965; Vanthemsche, 2001). In more general surveys of transportation networks in (colonial) Congo, the discussions on road infrastructure remain extremely concise (Headrick, 1981; Huybrechts, 1970; Nicolaï, 1996; Sabakinu Kivilu, 1979). Besides a noteworthy study on the development of motor vehicles in Belgian Congo (Tsund'olela, 1987), it is quite telling that the most informative source on the topic remains a technical report of 218 pages written by Egide-Jean Devroey, an engineer employed in the Ministry of Colonies (Devroey, 1939). This lack of research on road infrastructure is not specific to the Belgian colony, but can be extended to other studies on transportation in colonial Africa (Dix, 1931). One of the few scholars who did engage in studies on mobility in colonial and postcolonial Africa, Gordon Pirie, writes: 'compared to the railway, the road and its users have been something of a Cinderella in African transportation history' (Pirie, 1990, 2009, 2018).

4 Anno 2020, some scholars try to put research on colonial infrastructure back on the table (Cupers, 2018; Scotto 2018), although the study of road networks and car mobility in colonial Africa still remains in the margins (Gewald, 2002, 2009). Still, upcoming scholars convincingly argue that road infrastructure and the car mobility it enabled, provide a powerful lens to rethink colonial history by presenting 'alternative visions of space and power, autonomy and authority, mobility and control' (Hart, 2015, 2016). Nancy Rose Hunt provided a similar cultural perspective on the history of colonial mobility, studying the disruptive nature of new forms of mobility on African societies, and the struggles related to the simultaneous events of rural health care and forced road construction (Hunt, 1999). Furthermore, Freed's Networks of (colonial) power: roads in French Central Africa after World War I, studies roads and road work as 'sites of contestation over colonial rule and order', signalling the disruptive impact of the forced and technically simple road work on local populations (Freed, 2010). At the same 
time, recent contributions to the emerging field of the anthropology of infrastructure discuss how road infrastructure does more than only connect, it participates in the creation and recreation of social spaces (Rest, Rippa, 2019).

5 In Belgian Congo, the construction of a fine-grained road network coincides not unsurprisingly with the emergence of a colonial bureaucratic apparatus during the interwar years. This period in Congo's history has not received much scholarly attention until recent years (Petit, Vanderlinden, 2016; Vanderlinden, 2019). Contrarily to railroads that played a major role in linking emerging cities and thus helped structure the urbanisation of the colony, the road network in colonial Congo was more closely linked with the development of the countryside and the upcoming rural economy, a strategy that attracted new political interest after WWI. The rural economy of Belgian Congo has been overlooked for the major part in recent scholarship (Drachoussoff, 1991; Jewsiewicki, 1980, 1983) as most scholars tend to focus on the urban centres, although some noticeable exceptions can be found (Clement, 2007; Segers, 2016).

6 Looking at the often messy colonial reality in this 'periphery of the periphery' (Sengupta, 2010) allows us to investigate how centrally planned, top-down road policies were effectively implemented 'on the ground'. Starting from a detailed analysis of the interwar context of colonial road policies, this article elaborates on how the Belgian government considered the road network an essential component of the armature économique and wanted to stimulate its construction to efficiently access the colonial hinterland. Road infrastructure served as a means of control for Belgian colonial officials, via which they could penetrate this rural territory for medical, military, or administrative motives. A substantial part of the road infrastructure network provided the framework for the development of car-based tourism, which targeted both an 'internal' and an 'external' market from the 1930s onwards (Verhoeven, Payrhuber, 2019). Subsequently, the eighty-year-old technical report on road infrastructure written by Egide-Jean Devroey, an engineer employed in the Ministry of Colonies, is used to deconstruct the colonial administration's vision of a rational categorization and implementation of roads in the colonial territory (Devroey, 1939).

7 In the second part of this article, we contrast these government strategies with a close reading of the case of Victor Cooreman, a jute planter who wanted to install himself in the Cataractes-Nord region in 1928. After three years of correspondence between the entrepreneur and the various levels of government agents, Victor Cooreman ultimately convinced the Belgian government to finance a road crucial for the entrepreneur's activities, and to recruit indigenous labourers for the road's construction and maintenance. The detailed description of the case reveals the aptitude and agency of both a variety of government officials and private entrepreneurs, as well as the messy reality of how these policies landed and adapted 'on the ground'. At the same time, the internal correspondence within the government administration demonstrates the relatively of this colonial road infrastructure as tools of empire, as these centrallyplanned roads became 'tools' local actors used for their own intentions, in a complex web of knowledge and technology exchanges and interconnectedness (Arnold, 2005).

8 This article mainly builds upon research done in the Africa Archives, which are currently kept within the Ministry of Foreign Affairs in Brussels. Their collections predominantly contain records from the former Ministry of Colonies as well as a substantial part of the archives of the Gouvernement Général (GG), the central 
administration in Léopoldville. The majority of documents consulted were - internal and external - correspondence from both government apparatuses, combined with various maps produced by both the colonial government and by private colonial entrepreneurs. Drawing upon recent ideas in colonial historiography about the closereading of colonial archives (Allman, 2013; Stoler, 2009), this study is based on imperial sources in the context of the Master's dissertation of the author ${ }^{1}$, so native voices remain out of reach. Nevertheless, their agency can be partially highlighted through a detailed study of the strategies implemented by the colonial state to achieve their goals, be they profit maximisation or territorial control (Henriet, 2015).

By analysing the case of Victor Cooreman's road negotiation in the Cataractes-Nord region, we hope to provide useful insights in the nuanced realities of colonial road construction in order to add to the rising scholarship on localised agencies (Salami, 2016; De Nys-Ketels et al., 2019). At the same time, this case offers a powerful tool to critically reassess African transportation and planning history, which seems quite technical at first, but ultimately proves to be exceptionally layered.

\section{Road infrastructure as part of the colonial Armature économique}

10 At the end of the $19^{\text {th }}$ century, the road network in Belgian Congo was mainly limited to the Bas-Congo region, trying to secure the narrow carrier routes installed by Henry Morton Stanley in 1886 (Fig. 1, right-hand side). Even in the broader context of the African continent, only in the interwar years the first steps towards national and international colonial road networks were taken. In Belgian Congo, the launch of Minister of Colonies Louis Franck's investment plan in 1922 accelerated the development of different means of (cheap) transportation infrastructure (Vanhove, 1968). Louis Franck (1868-1937) was the liberal Minister of Colonies of Belgium between 1918 and 1924. He launched the so-called 'Plan Franck' on August 21, 1921, which consisted of a series of laws and regulations responding to the need for transportation infrastructure in order to stimulate private investment (Belgian Colonial Biography).

11 A second mayor element of the 'Plan Franck' was the decentralisation of the Belgian Ministry of Colonies by erecting seven Departments - or Directions Générales -, such as a department of Agriculture and one of Public Works. Since 1908, the Ministry of Colonies had ruled over Belgian Congo from Brussels, combining the legislative and executive power. A parallel, similarly organised administration operated in Léopoldville $^{2}$ (now Kinshasa) in Belgian Congo, called the General Government or Gouvernement Général. Led by the Gouverneur Général (Governor General), this apparatus encompassed several similar administrative branches, including a Léopoldville-based Public Works service. Additionally, the Gouvernement Général supervised subdepartments based in each of the four provincial capitals, which were named Gouvernements Provinciaux and led by Vice-Governors or Gouveneurs des Provinces (Vanhove, 1968; Vellut et al., 1996). Each of these Provinces was in turn divided into districts and territoires, the former led by a Commissaire de District. This complex machinery of the overseas government was limited to enacting specific or urgent laws set forth by the Brussels-based Belgian government. From their creation in 1908, both government apparatuses struggled with this parallel structure, and especially the government in Léopoldville was frustrated by its lack of legislative power. Informal 
dissent grew between the Brussels and Léopoldville government officials during the interwar period, and even within the different levels of the colonial government, the lower based officials argued for more decentralization. Moreover, struggles arose between the lowest ranks of the white colonial administrators on the field, the Administrateurs Territoriaux, and the various levels of African power who were appointed by the colonial authorities, such as the customary chiefs who often retained a degree of authority over local village populations (Vellut et al., 1996).

In addition to its economic and political narrative, the 'Plan Franck' represented a preliminary step in the Belgian governments' strategy of rationalising the organization of indigenous labour force. After the international critique on the forced labour practices and the way the Congo Free State was ruled before 1908, the Belgian government strove to project the image of a model colony to the world. From the 1920s onwards, representatives of Belgium took an active role in the composition of various international anti-slavery conventions in the newly established League of Nations. These covenants were of various effectiveness, as national governments interpreted them depending their own definition of the term 'forced labour' (Laqua, 2013). Note how particularly the Portuguese and Belgian governments argued during the 1920s that 'labour could be made compulsory not only for public works but for purposes of education and social welfare'. Although never officially against these conventions, the Belgian government postponed the ratification of the 1930s 'Forced Labour Convention' for over a decade, only wanting to accept the convention provided that it allowed for 'works of public interest, as determined by competent authorities' (Laqua, 2013). This clearly illustrates the Belgian government's conflicting motives concerning forced labour that benefitted the development of their colonie modèle or labour defined as 'educating the passive and lazy indigenous population' as part of a civilizing mission (Laqua, 2013). After WWII, these impromptu strategies accumulated in a shift of colonial policymaking towards what Young has called 'welfare colonialism' (Young, 1994), where the colonial extraction economy was reframed by associating it to major housing, healthcare and education investments (De Nys-Ketels et al., 2019).

Between 1927 and 1931, catholic politician Henri Jaspar (1870-1939) was almost without interruption both Prime Minister of Belgium and Minister of Colonies (Vanhove, 1958). Well aware of the rising international tensions, he wanted to reconcile the progress of Congolese industries with the possibilities and limitations of the local labour force. To this end, Jaspar had an in-depth investigation carried out in 1930 in Belgian Congo, which resulted in the publication of Expansion coloniale: étude documentaire sur l'armature économique de la colonie belge du Congo. This two-volume publication consisted of set of essays about the armatures that frame the economic expansion of the colony, such as agriculture, education, geology, legislation and transportation networks (Jaspar, Passelecq, 1932). Jaspar continued the politics of his predecessors in the creation of new railways and road networks, and the development of stations and ports, explicitly considering the road network an essential part of the armature économique. Based on this detailed survey, Jaspar established new recruitment standards in the various economic zones, arguing that this would lower the pressure on the indigenous population (Vanhove, 1968).

14 Although the road policies discussed in the 'Plan Franck' and Henri Jaspar's Expansion coloniale indirectly conceived road infrastructure as a tool of empire, they divulged little on how the Belgian government envisioned the implementation of their 
(inter)national transportation and labour politics 'on the ground'. Remarkably, the eighty-year-old Le Réseau Routier au Congo Belge et au Ruandi-Urundi (Devroey, 1939) is a key source to study the perception of colonial road policies in the Léopoldville-based colonial administration, as it remains the most complete source on the Belgian colonial road network until today. This technical report was written in 1939 by Egide-Jean Devroey (1894-1972), a prominent engineer employed by the Ministry of Colonies in Léopoldville (Belgian Colonial Biography), and reads as an accumulation of Devroey's two decades of experiences and frustrations with the ad hoc road construction policies in Belgian Congo (Fig. 1, left-hand side). Trying to respond to the struggles of implementing centrally-decided road policies in an extensive colonial territory over eighty times the size of Belgium, Devroey wrote an all-inclusive guide for the colonial government apparatus in order to offer each administrator, regardless of his rank in the colonial hierarchy, a set of objective criteria to guide the construction of a road in a rational and objective manner.

In the first part of the publication, Devroey distinguished between private and public roads, and divided the latter into three administrative categories. The primary and secondary public roads linked the rural economy with the supra-local rail and river networks, and were used for economic transportation of exploited goods. Additionally, the author discussed a third category: the routes pour voyageurs. These roads served no economic purpose, but offered administrative, political and tourist accessibility of the territory. They were a tool of control for Belgian colonial officials, via which they could penetrate this rural territory for medical, military or administrative motives. These routes pour voyageurs were used by bicycling nurses and linked the African rural population with the local missionary church.

Devroey further made a distinction between roads of intérêt général ('general interest') and of intérêt local ('local interest'). Roads of 'general interest' were defined as public roads that connected administrative centres of the colony, and were the only roads that could be financed by the Belgian state. Any public road that was not granted this status of intérêt général by the Gouverneur Général, automatically became a road of intérêt local. This seemingly practical set of guidelines was created to automatise an efficient access of the entire colonial territory, additionally prioritizing the construction of major roads that stimulated government control and economic expansion.

However, the analysis of interwar road construction in the Cataractes-Nord region discussed below will illustrate how this status of intérêt général was (mis)used both by private entrepreneurs and the various government officials to motivate their own agendas. A close reading of the correspondence between various government officials and Victor Cooreman, a private entrepreneur who wanted to establish his jute plantation in the region, offers new insights in the dissonant decision-making process of colonial road construction. Studying the genesis of the road between Luozi and M'bedi, the first road in the Cataractes-Nord territoire and the road Cooreman needed to access his plantation, reveals how the colonial road policies landed and were adapted 'on the ground' in this 'periphery of the periphery'. 
Figure 1. Left-hand side: Construction d'une route en forêt primaire. Route Mombasa-Avakubi, 1930. Right-hand side: La route des caravans.
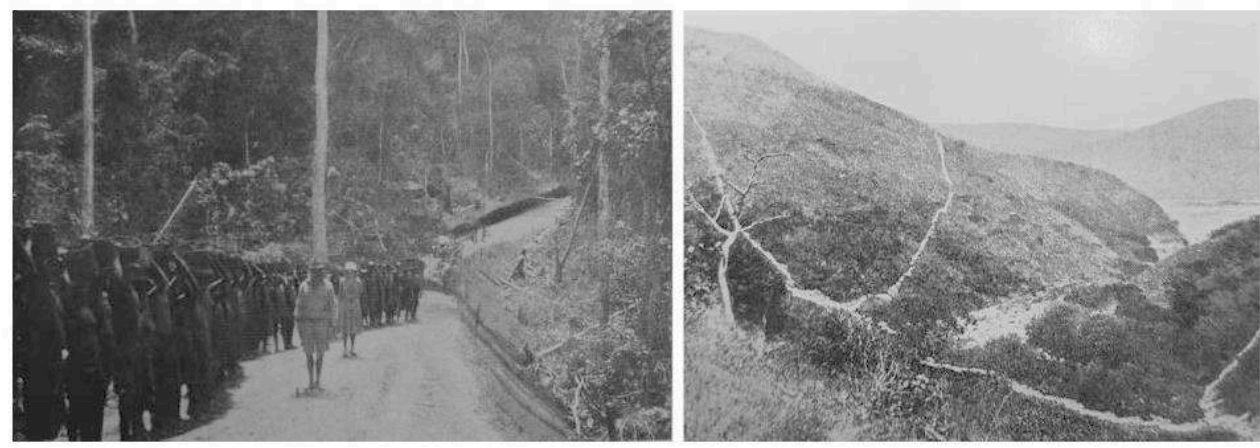

Devroey, 1939, p. 42; p. 16 (copyright requested by author)

\section{Jute economy as incentive for colonial road construction: the case of Victor Cooreman}

\section{Jute plantation in the Luala basin}

Victor Cooreman et Cie was established on February 1, 1923 with the purpose of the trade, import and export of cotton and jute fabrics, the manufacture of these fabrics, as well as all operations related to this trade'(Statute Books Belgium). Its main shareholder was Victor Cooreman (1879-1976), the son of catholic politician and businessman Gérard Cooreman (1852-1926), both members of a family active in the fibre industry and part of the bourgeois upper class of the city of Ghent. Gérard Cooreman was the founder and president of the 'Compagnie Cotonnière Congolaise' (COTONCO) since 1920 (Statute Books Belgium), and his son wanted to expand his professional activities in the colony by installing a jute plantation in the Luala basin.

This basic was defined as a triangular zone between the villages Luala, Dende and Kingila, and located in the remote Cataractes-Nord territory in the Bas-Congo region. Inaccessible by road or railroad infrastructure, Cooreman feared that the existing porterage route from Luala to Luozi would considerably delay the transportation of their jute harvest to Europe, so a road needed to be constructed to optimise their transportation process. Figure 2 illustrates the route the jute harvest took from the exploitation site to Europe (Fig. 2). Starting from the Luala basin (the red triangle), the harvest was transported by indigenous carriers to Luozi: a route of about 60 kilometres, depicted in a red dashed line on the map. Once arrived in Luozi, the jute got loaded upon canoes, which followed the river downstream to Kinganga. As the river became unnavigable shortly after Kinganga, the harvest was loaded upon trucks in this harbor and transported to Lufu, 55 kilometers southwards ${ }^{3}$. This road between Kinganga and Lufu was built by Gérard Cooreman at the beginning of the century to help transport his goods. In the city of Lufu, the Cooreman company had already established a trading post, where their goods arriving from Kinganga were reloaded. There, the produce boarded a train and was transported to the port city of Matadi via the LéopoldvilleMatadi railroad. 
Figure 2. Route of the jute from the Luala basin to Europe, 1928.

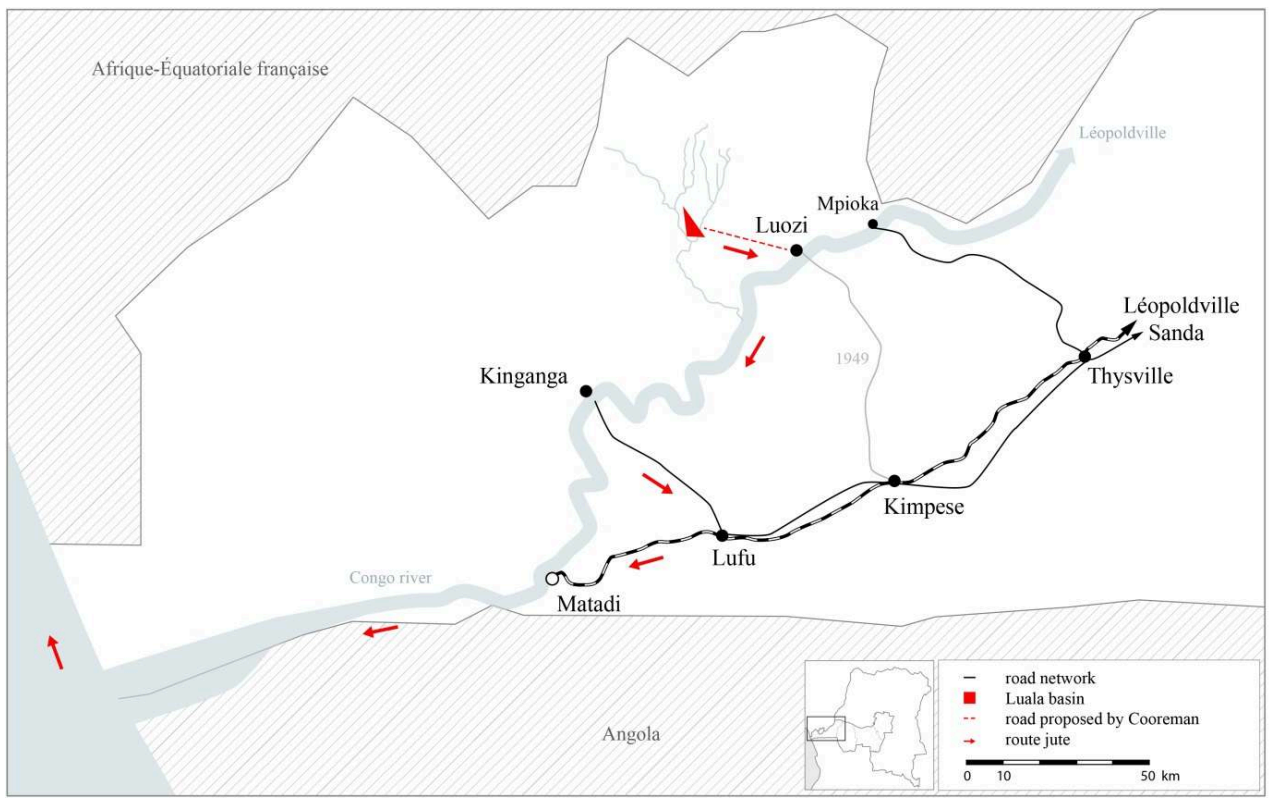

Cartography made by author ${ }^{4}$ exploitation site, the firm hired aristocrat Charles d'Yve(s) de Bavay (1885-1982) ${ }^{5}$ who was considered an agricultural expert with experience in the Dutch Indies (Laplae, 1926). He was tasked to travel to the Luala basin and investigate the possibilities of jute cultivation in the region. Besides describing the production process and the quality of the soil of the Luala basin, the agriculturist stated explicitly that a road needed to be constructed to efficiently access the exploitation site. In his analysis, he included a map on which he drew the demarcation the 'Luala basin', as well as the trajectory of the proposed road (Fig. 3). The map depicted various rivers and their affluents, as well as the mission posts present in the region (both Catholic and Protestant). Moreover, the indigenous villages and sentiers indigènes that connected them were visualised. The representation of these indigenous pathways is quite remarkable, as these sentiers indigènes were usually left out on government-drawn maps. d'Yves de Bavay furthermore distinguished between local villages and chefferies, the latter signifying a village with a type of higher administrative power. A single dashed line showed the trajectory of the road connecting the envisioned exploitation site to the port of Luozi, of which d'Yves de Bavay quoted in the corresponding letter: 'le tracé de cette route constitue un secteur d'une voie dont la construction est, paraît-il, prévue au budget's. This new road was seen as a continuation of a route planned by the government, however, our research did not find any sources in the government's archives to confirm this argument.

Analysing this map as an archival document in its own right, reveals how this region, and the colony in general, was not at all the 'terra nullius' the colonial government depicted in their cartographic vision for the colony. The presence of these sentiers indigènes represent one of the existing logics present in this rural countryside, which usually remained hidden in the colonial government's official correspondence and mapping on the region. Moreover, considering these private entrepreneurs as cartographic explorers opens up opportunities to investigate and reassess the local 
realities of road construction, and by extension, the historiography of colonial planning.

Figure 3. Luala basin.

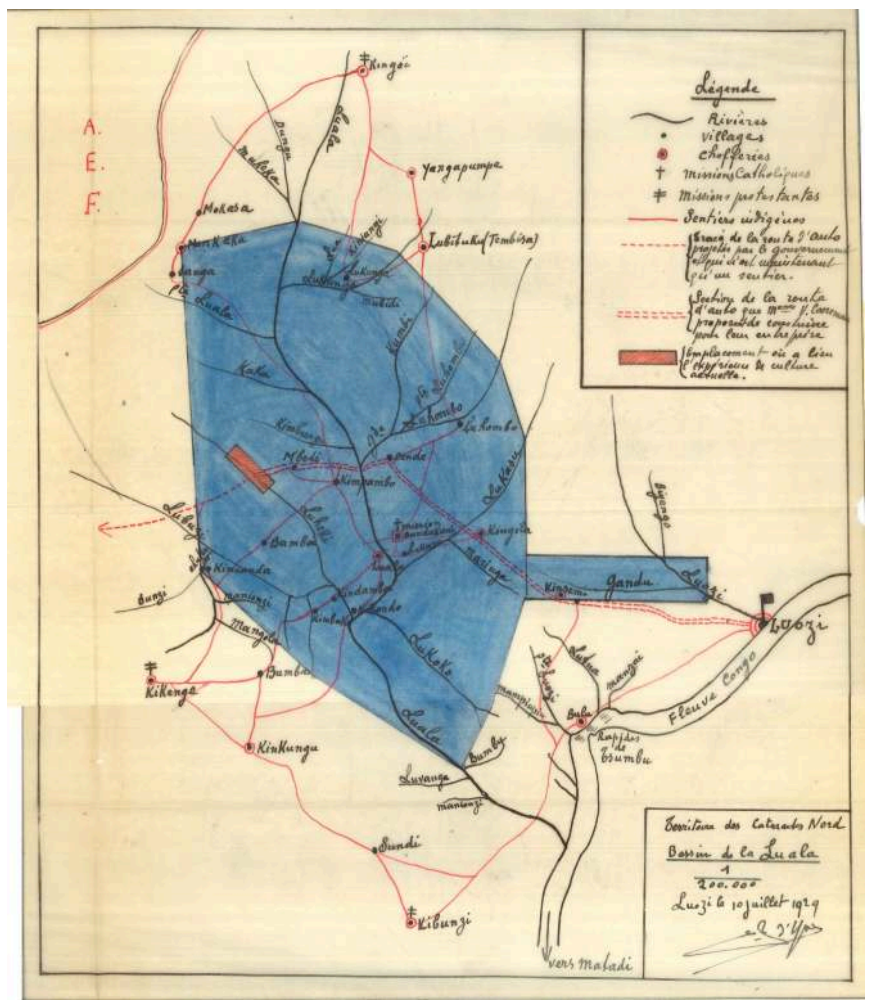

Africa Archives 3DG $1621 \mathrm{~N}^{\circ}$ 4250, December 7, 1929

\section{From private road to route d'intérêt général} exploitation of Victor Cooreman, officially, it should have been categorised as a private road, and thus commissioned and maintained by the entrepreneur himself. However, both the applicant's eloquent wording and the internal dissonance within the government apparatus allowed that the road was ultimately paid and maintained by the Belgian government, and even received the status of 'general interest'. Digging deeper in the correspondence between the jute planter and the colonial government discloses the complex history of road construction in this 'periphery of the periphery'. Furthermore, the intricate set of actors involved in the genesis of this road reveals a complex web of exchanges and interconnectedness between them, and questions colonial roads as tool of empire.

On June 28,1928 , Victor Cooreman demanded a concession for exploiting a fibre of the jute family in the Luozi region in the Bas-Congo. He requested a trial area of 100 hectares, under the condition of expanding later on if the experiment proved to be successful. The region the firm had set its minds on was bordered by the rivers Luhumbo, Luala and Lukasu, all affluents of the Congo River. The Luala basin, as they called it, was located 45 kilometres north-east of Luozi, in the triangular zone between villages Luala, Dende and Kingila ${ }^{7}$ (Fig. 3). 

to permit a trial area of such a size at the given time, seeing as the economic and social conditions of the Bas-Congo district did not allow extra industries ${ }^{8}$. As discussed above, the Belgian government refused to officially restrict the forced labour recruitment for 'public interest' throughout the interwar period. Jaspar thus most likely referred to the shortage of local workforce in the district, due to the mandatory recruitment of the indigenous population for construction of the Matadi-Léopoldville railroad in the BasCongo (Charlier, 2019). Moreover, the Luala basin was known for its low population density, due to the sleeping disease epidemics that plagued the region, amongst other reasons (Nicolaï, 1961). The forced recruitment and inhumane circumstances during the nine years of railroad construction for Matadi-Léopoldville railroad region (1923-1932) led to a widespread fear of the indigenous population for state recruiters, a topic which has been studied in a painstakingly detailed way (Marchal, 2000). Henceforth, the majority of the local population sought employment in other industries, resulting in the migration of young men to the mines of Congo-Brazzaville, as well as to other exploitation sites in neighbouring districts9. The colonial state tried to limit these forms of indigenous nomadism, wanting to contain the Congolese population within their territoires to control the pool of indigenous labour force (Henriet, 2015; Mathys, 2014). The letter finished with Minister Jaspar's suggestion that Cooreman should focus on developing a way to use more mechanical means of exploiting the area, signifying that an industrial culture with mechanical transportation would be easier to consider because it would put less pressure on the scarcely available local workforce. Furthermore, the mechanical transportation methods would suppress part of the porterage service that additionally strained the indigenous population. As the Cataractes-Nord territory had no transportation infrastructure to that date (see also Fig. 2), its location in the Bas-Congo district - the bottleneck for exported goods from the hinterland to Matadi - led to a major flux of goods between Léopoldville and Matadi, of which big parts had to be carried by the indigenous population (Fig. 1, right-hand side; Fontainas, 1921). Existing studies explain how the arrival of road transportation was welcomed by most of the native population in Belgian Congo, as jobs in porterage service were considered denigrating, and often carriers deserted their posts due to the harsh conditions (Samarin, 1985; Vansina, 2010; Wauters, 1924) ${ }^{10}$.

Cooreman wrote back several months later, on the October 5, 1928, with a renewed request for a trial area, along with the more demanding condition of reserving as much as 10,000 hectares for future exploitation. The company gave several reasons as to why the new concession would not put excessive pressure on the available indigenous workforce: 'Nous vous donnons l'assurance que, pour la mise en valeur de nos concessions, nous aurions recours au machinisme et aux transportations mécaniques, dans toute la mesure de nos moyens [...] La nature même de notre entreprise nous y obligerait indépendamment de notre désir de nous conformer à la politique du Gouvernement ${ }^{\prime 11}$. More remarkable is how the author literally quoted that they would not start the recruitment of labourers before the railroad works are completed. This illustrates how Cooreman was well aware of the problem concerning labour recruitment for railroad construction, and realised that they should not present themselves as competition for the government in terms of recruiting the local workforce. On December 3, 1928, the Gouverneur Général gave his 'principle agreement' 
to a concession of 100 hectares with the goal of establishing further exploitation of jute cultivation in the region, if the experiment proved to be successful.

In his following letter, the entrepreneur did no longer mention the government's recruitment for the railroad construction, but demanded that no other European enterprises will be allowed to occupy other parts of the region and approach its workforce. More precisely, Cooreman \& Co. requested aid in constructing the needed roads to access the new concession, as far as they were public roads of 'general interest', 'Pour ce qui est de la construction des routes, nous espérons que la colonie consentirait à nous donner l'aide nécessaire pour leur exécution et à intervenir dans la dépense pour autant qu'elles soient d'intérêt général ${ }^{12}$. Later that month, the Minister of Colonies gave his agreement on the extension, but asked the firm to specify the requested area as well as the demanded conditions. On December 2, 1929, the company specified their demand for a specific protection zone, and the government's help in recruiting workforce for the construction of the road from Luala to Luozi, using the map drawn by their representative in the territory, d'Yves de Bavay (Fig. 3). The emphasis of the request was no longer on financial assistance but on recruitment aid, as the firm was well aware it would be nearly impossible to prove that the road was a public road of 'general interest'. Recruiting local workforce at the same conditions as the government would not only result in financial profit for the company (as they would pay lower wages), it would also offer a better guarantee of workforce. As discussed before, the district struggled with shortage of local African labour force, and by granting the firm an official permit to recruit in a similar manner to the government, Cooreman \& Co. could have a bigger authority vis-à-vis the local workforce as well as the government recruiters, who were competing for the same scarce labourers. This request was entirely conflicting, as the discussed road would of course only serve the company, therefore it would have to be categorised officially as a private road, allowing it no governmental aid at all.

Dissonant reactions were given to this demand by the various levels of governmental authority in the colony, from the local Administrateur Territorial, to the Commissaire de District, the Gouverneur de Province, and ultimately the Gouverneur Général based in Léopoldville. The Agronome Provincial - the provincial agricultural administrator -, M. Peters, and the Administrateur Territorial of the Cataractes-Nord territory, M. Lecocq, both agreed to Cooreman's demands, arguing how the need for added revenues and decline of porterage service dominated when granting this protection zone in the region. Lecocq explained how the jute harvest of the trial area needed to be transported via Luozi-Kinganga-Lufu (Fig. 2), of which only the part between Luala and Luozi still needed to be constructed, which was now a porterage route that strains the local population at the time. He gave his opinion on how the construction could be done, under whose supervision, but never even considered that it may not be the government's responsibility to construct this private road to begin with.

The Commissaire de District of the district Bas-Congo, M. Morel, agreed with the recruitment conditions for the road, but stipulated that the local workforce should be paid by Cooreman. The manner in which the indigenous workforce would be recruited was not discussed in any of these letters, signalling that, although aware of the labour shortage, Cooreman's offer was seen as an optimal solution to keep the local workforce from migrating away from the territory. The focus was on the economic aspect of the cultivation, assuming that if more work was introduced in the area, the automatic 
response of the local population would be to stop migrating. The Commissaire Général, interim of the Provincial Governor of Congo-Kasaï, later sent this entire compilation of letters to the Gouverneur Général, narrowing down the request to the question if or if not the government should allow Cooreman extra privileges. However, the Commissaire Général claimed that no help should be offered to the firm at all as long as the trial was incomplete. No longer treating the road question as an independent request, he acted according to his own motives of not wanting his province to pay for the road's construction, nor wanting to strain the local population, and gave a negative reply to the request.

Various reasons can be discerned for this outcome. First of all, the construction of the railroad from Matadi to Léopoldville was, at that time, one of the biggest projects on the agenda of the Governor, as the completion of these infrastructure works would mean that the entire province of Bas-Congo could attract new investors. Take into account the (international) struggles concerning forced labour, the Governor would have been pressured to finish the railroad's construction as soon as possible. Although he was undoubtedly aware of the migration problems the lower government representatives discussed, the railroad's construction was the priority of his agenda. Any additional recruitment in the area, it being for advancement of the roads or for new cultivation practices, would further add to the recruitment problems the railroad already struggled with. By delaying the request until the results of the trial area were complete, he hoped to finish the railroad construction first, which was foreseen to be only six months later. In the end, the Gouverneur Général agreed with him, and sent a letter to the Minister of Colonies, in which he quoted that this was not an appropriate time to give extra concessions to Cooreman \& Co (July 25, 1930).

On August 7, an ambiguous decision was taken by the Minister of Colonies: he gave his principle agreement to Cooreman \& Co. for both the protection zone as well as the funding of the road construction, after the negative advice the Gouverneur Général provided. This decision seemed very contradictory, as Jaspar first demanded the local authorities' expertise, when he did not follow their advice later. Further research revealed that just the day before, he received positive recommendations from the Brussels-based colonial Departments of Agriculture and Economy to grant the demand of Cooreman \& Co. in order to stimulate extra investment in the area. However, the Gouverneur Général of the Léopoldville-based government did not agree with these recommendations, having given a negative advice just ten days earlier. Several explanations can be given for this difference of opinion. In general, we can ask ourselves if the Brussels-based Departments of Agriculture and Economy were aware of the depth of the population problems the Province of Bas-Congo struggled with. Nonetheless, the Department of Public Transportation, based in Brussels and a direct collaborator of the two former departments, was undoubtedly aware of the problems the railroad construction encountered. So both the Gouverneur Général and the Minister of Colonies should have been informed of these issues, making the latter's priority of keeping the Belgian entrepreneurs happy and stimulating extra investments in the colony even more telling.

31 The road was ultimately completed in August 1931, entirely paid by the government and constructed by the indigenous population, even though the Minister of Colonies himself literally quoted in the beginning of the discussion : 'Il est évident que si la route Luozi-Luala présente un caractère d'utilité publique, le Gouvernement peut envisager 
les moyens d'y faire des travaux ; par contre si elle n'a pour but direct que les intérêts privés de la firme susmentionnée, c'est à cette dernière qu'il appartient d'en supporter la charge ${ }^{\prime 13}$. Not only should the road, which was the first in the territory of CataractesNord, officially be categorised as a private road (which means government funding should be out of the question), if it were to be a public road, its 'general interest' is not proven at all, as the road does not connect provincial capitals, urban areas, or major cities. However, as discussed above, road infrastructure was considered an essential part of the armature économique and the colonial government in Belgium wanted to encourage all means of constructing transportation infrastructure in the region. Even if, at the time of its construction, the road officially only connected the new jute exploitation site to the river, therefore mainly serving the interests of Victor Cooreman, construction this road network of course aided the state's presence in this previously inaccessible region (Fontainas, 1921).

\section{Conclusion}

This article analyses how the Belgian colonial government conceived road infrastructure a tool of empire, and how its genesis is completely different from the wellstudied railroad network. Examining the case of Victor Cooreman demonstrates how the colonial state stimulated road construction projects in the previously inaccessible Cataractes-Nord region, as this new road network could help facilitate the state presence and surveillance in the colonial hinterland. Even if the road between M'bedi and Luozi at its origins only served the private interests of Victor Cooreman, making it easier for him to extract his jute from the colony, the road is ambiguously granted the status of 'general interest'. The colonial government authorised thus that the surrounding African population was obliged to construct and maintain this road, even if the abolishment of forced labour in the colonies was a rising topic in international debate at the time. This article therefore underscores the hypothesis that the colonial road network was linked to the infiltration and development of the colonial hinterland, and its construction and maintenance was all the more disruptive for local populations.

Although this article choses to focus on the relation between the government machinery and private entrepreneurship, the study of the development of the road network in the Cataractes-Nord region introduces a wider set of actors active in public road construction: missionary congregations, private investors, African labourers... and shows how the specific dynamic between them influenced the decision-making process of the road construction project 'on the ground'. The next step would be to investigate the impact of missionary congregations on the colonial road infrastructure project (Cleys et al., 2019; Cleys, De Meulder, 2011; Mahaniah, 1981). A detailed cartographic study of the evolution of the missionary, state, and privately constructed road networks after 1931 would offer valuable insights in both the geopolitical and economic motives of all actors involved. Additionally, this cartographic mapping should be completed by consulting the colonial archives in the capital of DRC and the archives of local missionary congregations, most of them still present in the DRC.

Still, the evolution of interwar road construction in the Cataractes-Nord region clearly illustrates how relative these roads as tools of empire were: in the hands of smart investors they become 'tools' to make a profit in a colony; in the hands of Africans 'tools' to avoid colonial power (Mathys, 2014); and even in the hands of different layers 
of the colonial administration they served different purposes. Headrick's tools of empire concept may be applicable to Belgian Congo's road construction, it is also superreducing. It conceals the complexity that occurs when introducing a 'technology' in a colonial context, where various local officials and private entrepreneurs have the agency to adapt these centrally-defined road policies in the 'on the ground' reality in the vast Congolese rural hinterland. This case provides thus already a powerful lens through which we can gain a better understanding of the forces at play in the transformation the road network brought about in the understudied Congolese countryside.

\section{BIBLIOGRAPHY}

ALLMAN J.M. (2013), "Phantoms of the archive: Kwame Nkrumah, a Nazi pilot named Hanna, and the contingencies of postcolonial history-writing", American Historical Review, 118, Washington D.C., American Historical Association, pp. 104-129.

ANON. (1928), Jaarlijksch verslag over het beheer der kolonie Belgisch-Congo, Brussel, Van Gompel.

ARNOLD D. (2005), "Europe, technology, and colonialism in the $20^{\text {th }}$ century", History and Technology, 21, 1, London, Routledge, pp. 85-106.

Belgian Colonial Biography, Brussels, Royal Academy for Overseas Sciences, https:// www.kaowarsom.be, consulted on 21/09/2020.

BLANCHART C. (1993), Le rail au Congo, Bruxelles, G. Blanchart \& Cie.

CHARLIER J. (2019), « Les transports ferroviaires au Congo pendant l'entre-deux-guerres », in VANDERLINDEN J. (ed.), The Belgian Congo between the Two World Wars, Brussels, Royal Academy for Overseas Sciences.

CLEMENT P. (2007), “The land tenure system in the Congo, 1885-1960”, in BUELENS F., Congo, 1885-1960: een financieel-economische geschiedenis, Berchem, EPO, 2007.

CLEYS B. \& DE MEULDER B. (2011), “Imagining a Christian Territory: Changing Spatial Strategies in the Missionary Outposts of Scheut (Kasai, Congo, 1891-1940)”, in DEMISSIE F., Colonial architecture and urbanism in Africa: intertwined and contested histories, Farnham, Ashgate.

CLEYS B., DE MAEYER J., DE MEULDER B. \& HOWARD A. (2019), Missionary Places, 1850-1950. Imagining, Building, Contesting Christianities, Leuven, Leuven University Press, KADOC Artes.

CUPERS K. (s.d.), How Infrastructure Shaped Territory in Africa. Research project supported by the Swiss National Science Foundation 2018-2022, Urban Studies, University of Basel, https:// criticalurbanisms.philhist.unibas.ch/projects/territorial-design.

DE NYS-KETELS S. et al. (2019), “Planning Belgian Congo's network of medical infrastructure: type-plans as tools to construct a medical model-colony, 1949-1959", Planning Perspectives, 34.

DEVROEY E. (1939), Le Réseau Routier au Congo Belge et au Ruandi-Urundi, Bruxelles, Van Campenhout, https://www.kaowarsom.be, consulted on 21/09/2020. 
DIX A. (1931), Was geht uns Afrika an? : das heutige Afrika in Weltwirtschaft, Weltverkehr, Weltpolitik, Berlin.

DRACHOUSSOFF V., HECQ J. (1991), Le développement rural en Afrique centrale 1908-1960/1962 : synthèse et réflexions, Beverly Hills, Sage.

FONTAINAS P. (1921), « La Politique des transports au Congo Belge », Bulletin de la Société Belge des Ingénieurs et des Industriels, 2.

FREED L. (2010), "Networks of (colonial) power: roads in French Central Africa after World War I", History and Technology, 26, 3, pp. 203-223.

GEWALD J.-B. (2002), "Missionaries, Hereros and Motorcars: Mobility and the Impact of Motor Vehicles in Namibia before 1940", International Journal of African Historical Studies, 35, 2/3, pp. 257-285.

GEWALD J.-B. (2009), The speed of change: motor vehicles and people in Africa, 1890-2000, Leiden, Brill.

HART J. (2015), Automobility, Technopolitics and African Histories of Technology-in-Use in $20^{\text {th }}$ century Ghana, paper presented at Technology's Stories: Past and Present, October 2015.

HART J. (2016), Ghana on the go: African mobility in the age of motor transportation?, Bloomington, Indiana University Press.

HEADRICK D. (1981), The tools of empire: Technology and European Imperialism in the Nineteenth Century, New York, Oxford University Press.

HEINDRYCKX L., LAGAE J., PELEMAN D. (2016), Forging Congo's road network. Scenes of dissonance within the colonial project, unpublished Master's Dissertation, Ghent, Ghent University.

HENRIET B. (2015), "Elusive natives: escaping colonial control in the Leverville oil palm concession, Belgian Congo, 1923-1941", Canadian Journal of African Studies / Revue canadienne des études africaines, 49, pp. 339-361.

HUNT N.R. (1999), A colonial lexicon of birth ritual, medicalization, and mobility in the Congo, Durham, Duke University Press.

HUYBRECHTS A. (1970), Transports et structures de développement au Congo. Etude du progrès économique de 1900 à 1970, Louvain, UCL/Mouton.

JASPAR H. \& PASSELECQ F. (1932), Expansion coloniale : étude documentaire sur l'armature économique de la colonie belge du Congo, Bruxelles, Desmet-Verteneuil.

JEWSIEWICKI B. (1980), "African peasants in the totalitarian colonial society of the Belgian Congo", in MARTIN K., Peasants in Africa: Historical and Contemporary Perspectives, Beverly Hills, Sage, pp. 36-53.

JEWSIEWICKI B. (1983), "Rural Society and the Belgian colonial economy", in MARTIN P.M., BIRMINGHAM D. (eds.), The History of Africa, vol. 2, London, Longman, pp. 95-125.

KATZENELLENBOGEN S.E. (1973), Railways and the Copper Mines of Katanga, London, Oxford University Press.

LAPLAE E. (1926), « La culture de l'Hévéa au Congo Belge », Revue de botanique appliquée et d'agriculture coloniale, 6, 56, pp. 204-218.

LAQUA D. (2013), The age of internationalism and Belgium, 1880-1930: peace, progress and prestige, Manchester, Manchester University Press, pp. 59-68.

LEDERER A. (1965), Histoire de la navigation au Congo, Tervuren, MRAC. 
MAHANIAH K. (1981), L'impact du christianisme au Manianga 1880-1980, Kinshasa, CVA.

MARCHAL J. (2000), Travail forcé pour le rail : l'histoire du Congo 1910-1945, Borgloon, Bellings.

MATHYS G. (2014), People on the move: frontiers, borders, mobility and history in the Lake Kivu region $19^{\text {th }}-20^{\text {th }}$ century, Ghent, Ghent University (Unpublished PhD).

NICOLAÏ H. et al. (1996), L'espace zaïrois : hommes et milieux : progrès de la connaissance de 1949 à 1992, Bruxelles, CEDAF.

NICOLAÏ H. (1961), Luozi : géographie régionale d’un pays du Bas-Congo, Bruxelles, ARSOM.

PELEMAN D. (2013), "Les Hommes de la Route": engineering the urban society of the modern road in Belgium, 1889-1962, Ghent, Ghent University (Unpublished PhD).

PETIT P. \& VANDERLINDEN J. (2016), The Belgian Congo between the Two World Wars, Book of Abstracts, Brussels, ARSOM.

PIRIE G. (1990), "Race, class and comfort on rural buses, 1925-1955”, Contree, 27, pp. 5-11.

PIRIE G., MOM G.P.A. \& TISSOT L. (2009), Mobility in history: the state of the art in the history of transport, traffic and mobility, Neuchâtel, Presses universitaires suisses.

PIRIE G. (2018), A Sub-Saharan African Transport Research Bibliography, African Centre for Cities, University of Cape Town.

REST M., RIPPA A. (2019), "Road animism: Reflections on the life of infrastructures", Journal of Ethnographic Theory, 9, 2, pp. 373-389.

SABAKINU KIVILU J. (1979), «La dynamique de l'espace du Bas-Zaïre. Quelques données d'analyse sur les voies de communication de 1885 à 1938 », Cultures et développement, 40, 2, pp. 249-251.

SALAMI I.O. (2016), The Architecture of the Public Works Department (PWD) in Nigeria During the Early to mid-Twentieth Century, PhD dissertation, University of Liverpool, Liverpool.

SAMARIN W. (1985), “The state's Bakongo burden bearers”, in COQUERY-VIDROVITCH C., LOVEJOY P.E. (eds.), The Workers of African Trade, Beverly Hills, Sage, pp. 269-292.

SCOTT J. (1998), Seeing like a state, New Haven, Yale University Press.

SCOTTO G. (2018), "Colonial and Postcolonial Logistics”, The Architecture of Logistics, Footprint, 23, 12, 2, Delft Architecture Theory Journal, pp. 69-86.

SEGERS Y., VAN MOLLE L. (forthcoming), Landbouw in tropisch Afrika. Agrarische wetenschap en kennisnetwerken in Belgisch Congo, Leuven University, FWO Project, 2012-2016.

SENGUPTA T. (2010), Producing the Province: Colonial Governance and Spatial Cultures in District Headquarter Towns of Eastern India 1786-c.1900, University of Westminster (Unpublished PhD's thesis).

Statute Books of Belgium, consulted in the Royal Library of Belgium in Brussels and via https:// data.be/, September 2020.

STOLER A. (2009), Along the archival grain: epistemic anxieties and colonial common sense, Princeton, Princeton University Press.

TSUND'OLELA E. (1987), “Motor transport in a developing area: Zaire, 1903-1959”, in BARKER Th. C. (ed.), The Economic and Social Effects of the Spread of Motor Vehicles: An International Centenary Tribute, Basingstoke, MacMillan, pp. 236-255.

VANDERLINDEN J. (ed.) (2019), The Belgian Congo between the Two World Wars, Brussels, Royal Academy for Overseas Sciences. 
VANHOVE J. (1968), Histoire du Ministère des Colonies, Bruxelles, Académie Royale des Sciences d'Outre-Mer.

VANSINA J. (2010), Being Colonized: The Kuba experience in rural Congo, 1880-1960, Madison, University of Wisconsin Press.

VANTHEMSCHE G. (2001), La Sabena et l'aviation commerciale belge 1923-2001, Bruxelles, De Boeck.

VELLUT J.-L., LORIAUX F., MORIMONT F. (1996), Bibliographie historique du Zaïre à l'époque coloniale (1880-1960) : travaux publiés en 1960-1996, Centre d'histoire de l'Afrique, Louvain-la-Neuve.

VERHOEVEN G. \& PAYRHUBER N. (2019), « 'Les pèlerins de la saison sèche' : Colonial Tourism in the Belgian Congo, 1945-60 », Journal of Contemporary History, 54, 3, pp. 573-593.

WAUTERS J. (1924), Le Congo au Travail, Bruxelles, Eglantine.

YOUNG C. (1994), The African Colonial State in Comparative Perspective, New Haven, Yale University Press.

\section{NOTES}

1. This paper draws mainly upon the research done in the context of the Master's dissertation: HEINDRYCKX, LAGAE, PELEMAN (2016), Forging Congo's road network. Scenes of dissonance within the colonial project, Ghent, Ghent University (Unpublished Master's dissertation).

2. To represent the historical sources accurately, this article uses the colonial names of the loci described in this paper.

3. Firmes: Compagnie des produits du Congo, Compagnie du Congo pour le commerce et l'industrie cominière, Société de Colonisation Agricole au Mayumbe, Colbalco Agricongo, Crédit Foncier, Africain American Congo Company, Syndicat Cooreman, Africa Archives, Ministry of Foreign Affairs, Brussels, Fund GG, file 18276.

4. This map is drawn by the author, based on the correspondence between M. d'Yves de Bavay and Victor Cooreman (Africa Archives, Ministry of Foreign Affairs, Brussels, Fund 3DG, file 1621 $\mathrm{N}^{\circ} 4250$, December 7, 1929), as well as on maps consulted in the Africa Archives: Carte Administrative et Voies de communication du Congo Belge, 1926 (Africa Archives, Ministry of Foreign Affairs, Brussels, Cartography Fund, file $\left.384 \mathrm{~N}^{\circ} 7023\right)$ / Congo Belge. Carte Politique et Administrative. Service Cartographique du Ministère des Colonies, 1935 (Africa Archives, Ministry of Foreign Affairs, Brussels, Cartography Fund, file $\left.146 \mathrm{~N}^{\circ} 10\right)$.

5. Biography of Charles d'Yve de Bavay, www.geneanet.org (consulted on September 28, 2020).

6. Africa Archives, Ministry of Foreign Affairs, Brussels, Fund 3DG, file $1621 \mathrm{~N}^{\circ} 4250$, December 7 , 1929.

7. Africa Archives, Ministry of Foreign Affairs, Brussels, Fund T27, file $\mathrm{N}^{\circ} 1486$, June 12, 1928.

8. Africa Archives, Ministry of Foreign Affairs, Brussels, Fund T27, file $\mathrm{N}^{\circ} 1486$, July 5, 1928.

9. ANON (1928), Jaarlijksch verslag over het beheer der kolonie Belgisch-Congo, Brussels, Van Gompel.

10. Ibid.

11. Africa Archives, Ministry of Foreign Affairs, Brussels, Fund T27, file $\mathrm{N}^{\circ} 2184$, October $5,1928$.

12. Africa Archives, Ministry of Foreign Affairs, Brussels, Fund T27, file $\mathrm{N}^{\circ} 3702$, July $5,1929$.

13. Africa Archives, Ministry of Foreign Affairs, Brussels, Fund 3DG, file $1621 \mathrm{~N}^{\circ} 1448$ December $16,1929$. 


\section{ABSTRACTS}

Contrary to the well-recognised relation between railroad infrastructure and emerging cities in the Belgian colony, the development of the Congolese road network was more closely connected to accessing the colonial hinterland and the expanding the rural economy. This latter link remains underresearched in both Congo's and Africa's transportation history, even if the colonial government equally considered road infrastructure a tool of empire. This article deconstructs this super-reducing concept of tools of empire in search of a better understanding of the complex reality of how centrally-defined road policies landed 'on the ground' in the vast Congolese hinterland. Studying the interwar development of the road network in the Cataractes-Nord region demonstrates how everyday colonial policymaking relied deeply on the aptitude and agency of private entrepreneurs and government officials alike, in a first step to truly understand the forces at play in the opening up of the Congolese countryside.

Contrairement à la relation bien reconnue entre le développement de l'infrastructure ferroviaire et les villes émergentes de la colonie belge, le développement du réseau routier congolais était plus étroitement lié à l'accès à l'arrière-pays colonial et à l'expansion de l'économie rurale. Ce dernier lien reste trop peu investigué dans l'histoire des transports au Congo et en Afrique, même si le gouvernement colonial considérait également l'infrastructure routière comme un «tool of empire » (« outil d'Empire »). Cet article déconstruit ce concept réducteur de " tool of empire » en cherchant à mieux comprendre la réalité complexe de la façon dont les politiques routières du niveau central ont été transposées sur le terrain dans l'arrière-pays congolais. L'étude du développement du réseau routier pendant l'entre-deux-guerres dans la région des Cataractes-Nord montre comment l'élaboration quotidienne des politiques routières coloniales reposait considérablement sur l'aptitude et la capacité d'action des entrepreneurs privés et des fonctionnaires du gouvernement, dans un premier temps pour comprendre les forces en jeu dans l'ouverture de la campagne congolaise.

\section{INDEX}

Mots-clés: réseau routier, Congo Belge, bureaucratie, industrie, tool of empire (« outil d'Empire »)

Keywords: road network, Belgian Congo, bureaucracy, industry, tool of empire

\section{AUTHOR}

\section{LAURENCE HEINDRYCKX}

PhD student, Dept. of Architecture \& Urban Planning, Ghent University, Ghent, Belgium, Laurence.Heindryckx@ugent.be 